\title{
PENYULUHAN BALITA BGM DI DESA WARGA INDAH JAYA KECAMATAN BANJAR AGUNG KABUPATEN TULANG BAWANG
}

\author{
Dainty Maternity ${ }^{1}$, Yuli Yantina² \\ 1,2 Prodi DIV Kebidanan \\ Email: denty.mf@gmail.com, yyantina42@gmail.com
}

\begin{abstract}
ABSTRAK
Gerakan Masyarakat Peduli Gizi Balita (GEMPITA) yang artinya mengajak masyarakat yang memiliki anak di bawah lima tahun (Balita) untuk memberikan makanan tambahan yang cukup bagi anaknya agar kekurangan gizi tidak terjadi di dalam kelurga mereka. Berdasarkan data terdapat 2 balita yang mengalami BGM. Sehingga diadakan penyuluhan mengenai gizi balita yang dapat meningkatkan berat badan bayi agar tidak terjadi kekurangan gizi pada anak. Penyuluhan ini diadakan agar ibu dapat mengerti dan menerapkan apa yang sudah dijelaskan. Metode ceramah, diskusi, dan tanya jawab agar masyarakat dapat lebih paham dari apa yang sudah di jelaskan. Rekomendasi kegiatan ini adalah perlunya pemantauan secara berkala pada berat badan dan tinggi badan balita untuk mengetahui balita tidak ada yang berada di BGM atau pun mengalami kekurangan gizi.
\end{abstract}

Kata Kunci : Kacang Hijau, Telur Rebus, Balita, Status Gizi

\section{ABSTRACT}

The Community Care for Nutrition for Toddlers Movement (GEMPITA), which means inviting people who have children under five years of age (toddlers) to provide adequate supplementary food for their children so that malnutrition does not occur in their families. Based on the data obtained, there are 2 toddlers who experience BGM. So that there is counseling about the nutrition of toddlers which can increase the baby's weight so that there is no malnutrition in children. This counseling is held so that mothers can understand and apply what has been explained. Methods of lecturing, discussion, and question and answer so that the public can better understand what has been explained. The recommendation for this activity is the need for regular monitoring of the weight and height of children under five to find out that none of them are in BGM or have malnutrition.

Keywords: Green Beans, Boiled Eggs, Toddler, Nutritional Statu

\section{PENDAHULUAN}

Dalam rangka menerapkan upaya gizi seimbang, setiap keluarga harus mampu mengenal, mencegah, dan mengatasi masalah gizi setiap anggota keluarganya. Hal ini sesuai dengan Peraturan Menteri Kesehatan Nomor 23 Tahun 2014 
tentang Upaya Perbaikan Gizi. Adapun upaya yang dilakukan untuk mengenal, mencegah, dan mengatasi masalah gizi yaitu dengan cara menimbang berat badan secara teratur,menu makanan yang bervariasi,menggunakan garam beryodium. (Profil Kesehatan Indonesia, 2020).

Penimbangan balita merupakan salah satu kegiatan yang dilakukan dalam pemantauan pertumbuhan. Pemantauan pertumbuhan setiap bulan bertujuan sebagai deteksi dini untuk mencegah terjadinya gagal tumbuh kembang pada balita. Dengan rutin menimbang balita, maka pertumbuhan balita dapat dipantau secara intensif. Jika diketahui berat badan anak tidak naik atau jika ditemukan anak menderita suatu penyakit, dapat segera dilakukan upaya pemulihan dan pencegahan, agar tidak menjadi gizi kurang atau gizi buruk. Semakin cepat ditemukan, kasus gizi kurang atau gizi buruk akan semakin cepat ditangani. Penanganan yang cepat dan tepat sesuai tata laksana kasus anak gizi kurang atau gizi buruk akan mengurangi risiko kematian sehingga angka kematian akibat gizi buruk dapat ditekan.

Persentase rata-rata balita umur 6-59 bulan yang ditimbang di Indonesia pada tahun 2019 adalah 73,86\% anak per bulan. Persentase tertinggi terdapat di Provinsi Sumatera Utara yaitu sebesar $96,69 \%$, sedangkan persentase terendah terdapat di Provinsi Papua yaitu sebesar 30,11\%. Di Provinsi Lampung Penimbangan Balita tercatat sebesar 79,83\%. (Profil Kesehatan Indonesia, 2020).

Persentase balita kurus mendapat PMT di Indonesia tahun 2019 adalah 89,64\%. Angka ini belum memenuhi target Renstra tahun 2019 yaitu sebesar 90\%. Di Provinsi Lampung persentase balita kurus sudah tercatat sebanyak $89,45 \%$ (Profil Kesehatan Indonesia, 2020).

Dari hasil pendataan survey mawas diri pada awal bulan Maret 2021 terdapat adanya kesenjangan data tentang berat badan bayi dengan umur bayi sebesar $100 \%$, dan dari wawancara saat kunjungan rumah serta saat melakukan kegiatan kelas ibu dan balita terdapat 2 balita yang berat badan tidak sesuai dengan umur balita.

Ibu yang memiliki anak balita harus memperhatikan pola makanan yang bergizi dan makanan tambahan pada anak agar anak tidak berada di posisi BGM atau bahkan sampai kekurangan gizi. Untuk meningkatkan kandungan gizi, bahanbahan tersebut dapat disubstitusi dengan bahan pangan lokal sumber protein dan vitamin. Salah satu bahan pangan lokal yang bernilai gizi tinggi yang dapat dimanfaatkan sebagai bahan makanan tambahan yang mudah dijangkau masyarakat adalah kacang hijau. Kacang hijau (Phaseolus Radiatus) memiliki kandungan nutrisi diantaranya karbohidrat yang merupakan komponen terbesar dari kacang hijau yaitu sebesar $62-63 \%$. Kandungan lemak pada kacang hijau adalah 0,7-1 gr/kg kacang hijau segar yang terdiri atas $73 \%$ lemak tak jenuh dan $27 \%$ lemak jenuh, sehingga aman dikonsumsi. Berdasarkan jumlahnya, protein merupakan penyusun utama kedua setelah karbohidrat. Kacang hijau mengandung $20-25 \%$ protein. Protein pada kacang hijau mentah memiliki daya 
cerna sekitar $77 \%$. Selain kacang hijau salah satu sumber protein hewani yang dibutuhkan oleh tubuh yaitu dipenuhi dengan konsumsi telur. Kandungan gizi telur terdiri dari : air 73,7\%, Protein 12,9\%, Lemak 11,2\% dan Karbohidrat 0,9\%. (Suksesty, Catur Erty, dkk, 2020)

\section{MASALAH}

Alasan kamimemilih tempat kegiatan karena di Desa Warga Indah Jaya Kecamatan Banjar Baru Kabupaten Tulang Bawang didapatkan hasil bahwa banyak orang tua yang belum mengetahui mengenai makanan tambahan yang mencukupi bagi balita.

\section{PETA DESA WARGA INDAH JAYA TULANG BAWANG}

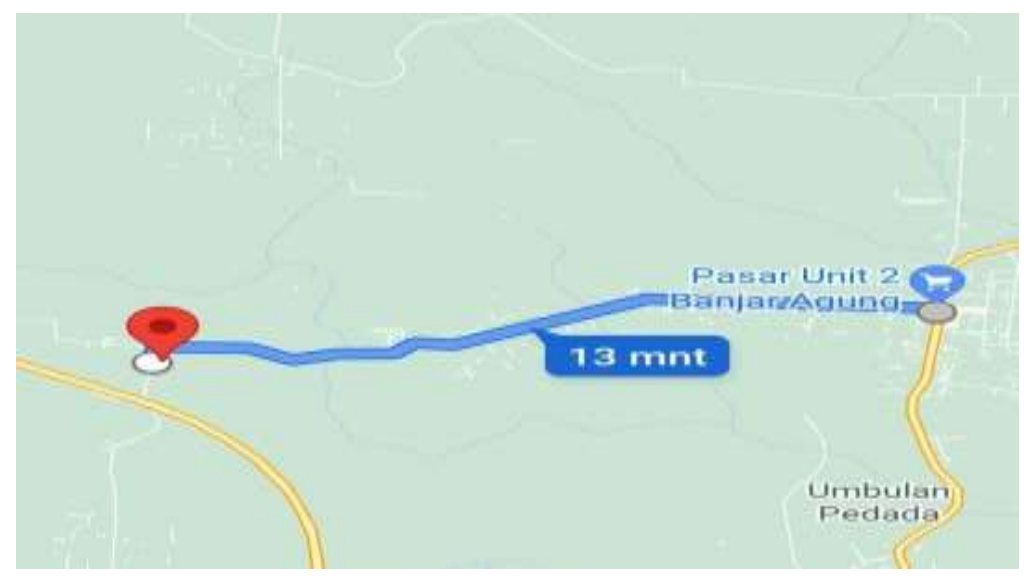

\section{METODE}

Penelitian dilakukan di desa Warga Indah Jaya Tulang Bawang pada tanggal 8 April sampai 4 Mei 2021 dengan memberikan penyuluhan edukasi tentang manfaat kacang hijau dan telur rebus terhadap peningkatan berat badan balita serta cara pengolahan aneka makanan olahan kacang hijau dan telur kepada ibu yang memiliki anak balita.

a. Tujuan Persiapan

Tahap persiapan dari kegiatan adalah pre planning, persiapan penyajian dengan lcd, ppt.

b. Tahap Pelaksanaan tanggal 08 April 2021 jam 09.00 WIB

c. Acara ini dengan pemberitahuan kepada Kepala Kampung, Kepala Desa Warga Indah Jaya untuk meminta izin mengadakan penyuluhan tentang gizi balita pada msayarakat yang memiliki balita di desa Warga Indah Jaya.

\section{HASIL DAN PEMBAHASAN}

Metode pelaksanaan dalam kegiatan penyuluhan mengenai gizi balita yang dilaksanakan pada tanggal 08 April 2021 di Gedung Posyandu Warga Indah Jaya Kecamatan Banjar Baru Kabupaten Tulang Bawang. Metode yang digunakan adalah ceramah, Tanya jawab atau evaluasi. 


\section{Kacang Hijau}

Kacang hijau (Phaseolus Radiatus) memiliki kandungan nutrisi diantaranya karbohidrat yang merupakan komponen terbesar dari kacang hijau yaitu sebesar 62-63\%. Kandungan lemak pada kacang hijau adalah 0,7-1 gr/kg kacang hijau segar yang terdiri atas 73\% lemak tak jenuh dan $27 \%$ lemak jenuh, sehingga aman dikonsumsi. Berdasarkan jumlahnya, protein merupakan penyusun utama kedua setelah karbohidrat. Kacang hijau mengandung 20-25\% protein. Protein pada kacang hijau mentah memiliki daya cerna sekitar $77 \%$ (Suksesty, Catur Erty, dkk, 2020).

Kacang Hijau dapat diolah menjadi beberapa olahan seperti :

a. Bubur kacang hijau

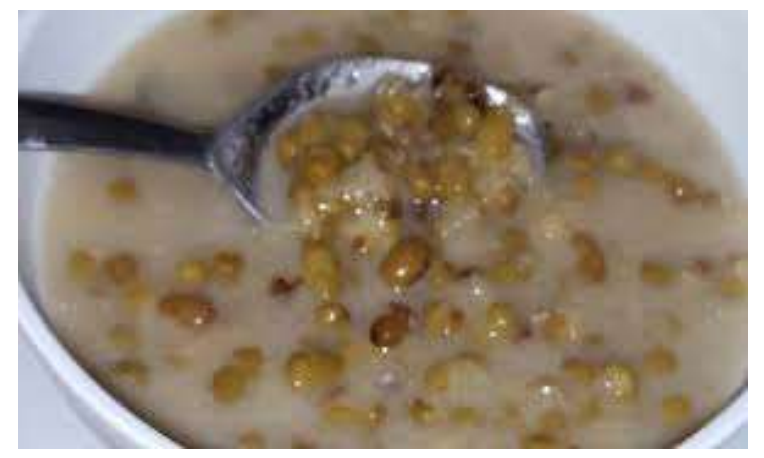

\section{Bahan-bahan}

1) 100 gram kacang hijau

2) 5 gelas air

3) 100 gram gula pasir

4) Garam (secukupnya)

5) 50 gram gula merah (potong halus)

6) Jahe (sesuai selera)

7) $100 \mathrm{ml}$ santan kelapa

Cara membuat bubur kacang hijau

1) Cuci bersih kacang hijau, rendam kira-kira selama 30 menit

2) Rebus kacang hijau bersama 5 gelas air hingga mendidih dan empuk atau mekar

3) Tambah gula pasir, gula merah, jahe dan garam secukupnya

4) Rebus semua bahan hingga gula mencair dan meresap ke kacang hijau

5) Jika bubur kacang hijau dirasa sudah matang dan empuk sempurna, tambah santan kelapa

6) Koreksi rasa dan tambahkan gula maupun garam untuk mendapatkan rasa yang sempurna

7) Rebus dan aduk bubur kacang hijau sampai mendidih dan benar-benar matang

8) Angkat dan sajikan selagi masih hangat 
b. Jus kacang hijau

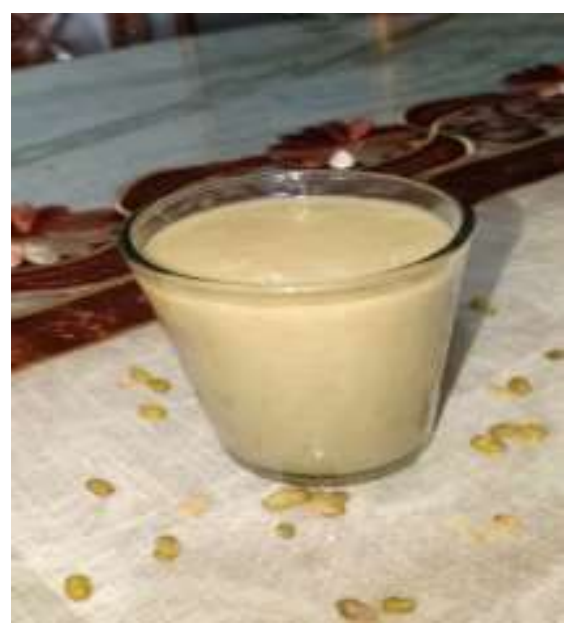

Bahan-bahan

1) 250 gram kacang hijau

2) $750 \mathrm{ml}$ air mineral

3) Es batu

Kuah santan didihkan:

1) $250 \mathrm{ml}$ santan kental, dari $1 / 2$ butir kelapa parut

2) $1 / 2 \mathrm{sdt}$ garam

Sirop gula, didihkan :

1) 150 gram gula pasir

2) $100 \mathrm{ml}$ air mineral

Cara membuat jus kacang hijau

1) Rendam kacang hijau semalaman dan tiriskan

2) Rebus kacang hijau bersama air hingga matang dan tiriskan

3) Saat kacang hijau sudah tidak panas haluskan menggunakan blender hingga mengental

4) Jus kacang hijau siap di sajikan ke dalam gelas

5) Tambahkan $2 \mathrm{sdm}$ kuah santan dan $1 \mathrm{sdm}$ sirop gula atau sesuai selera

6) Jika ingin jus kacang hijau dingin tambahkan es batu di dalam gelas

c. Puding kacang hijau 


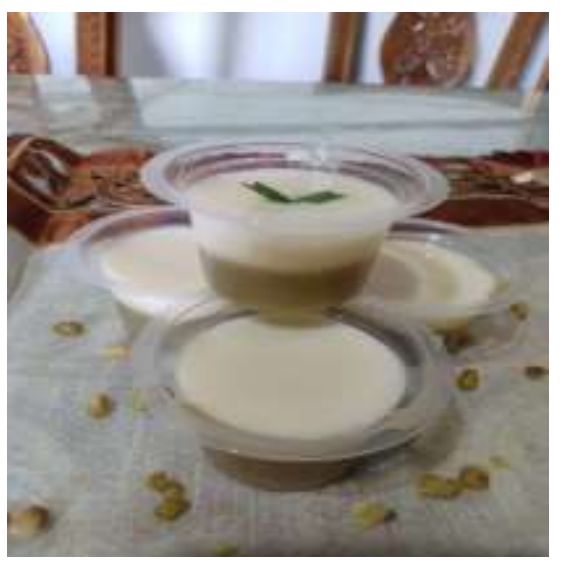

Bahan-bahan :

1) 1 bungkus agar-agar bening

2) 150 gram kacang hijau

3) $65 \mathrm{ml}$ santan kelapa

4) 100 gram gula pasir

5) 50 gram gula jawa

6) $1 / 3$ sdt garam

7) $500 \mathrm{ml}$ air mineral

Cara membuat pudding kacang hijau

1) Rebus kacang hijau sampai empuk lalu tiriskan

2) Setelah dingin kacang hijau di blender sampai halus

3) Siapkan panci lalu masukkan kacang hijau, santan, gula jawa, gula pasir, garam secukupnya, dan agar-agar aduk sebentar

4) Nyalakan api lalu masuk pudding sambil diaduk-aduk hingga mendidih

5) Tuangkan pudding ke dalam cap kecil lalu biarkan dingin dan simpan di dalam kulkas

6) Setelah 30 menit pudding dapat disajikan dan di makan

Penimbangan Berat Badan Balita di Posyandu Warga Indah Jaya 


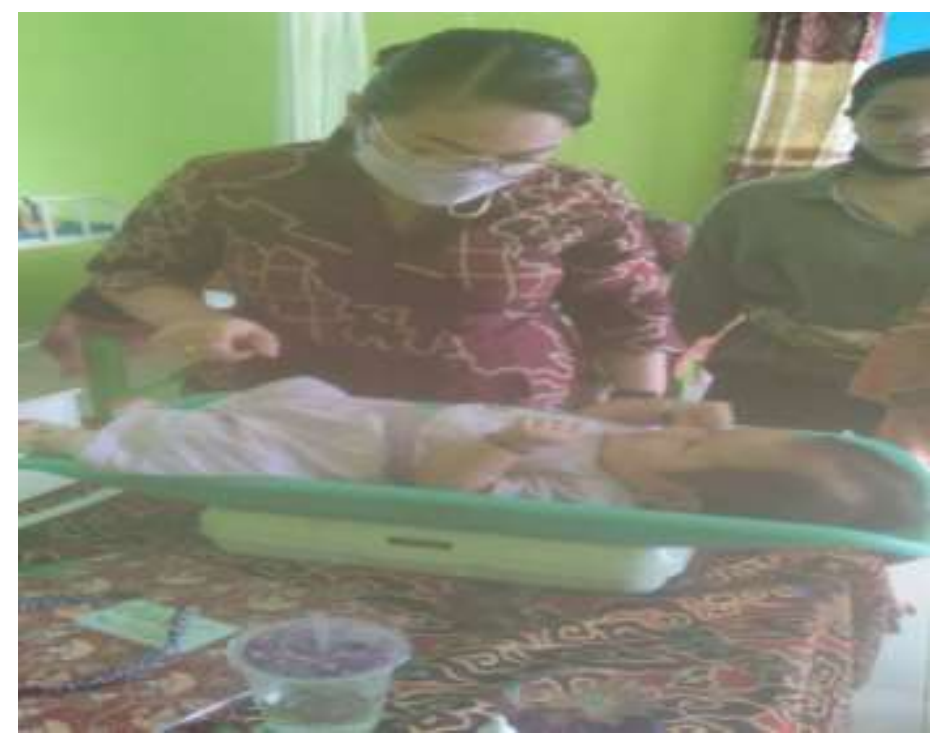

Pemberian Makanan Tambahan Berbahan Kacang Hijau dan Telur Rebus

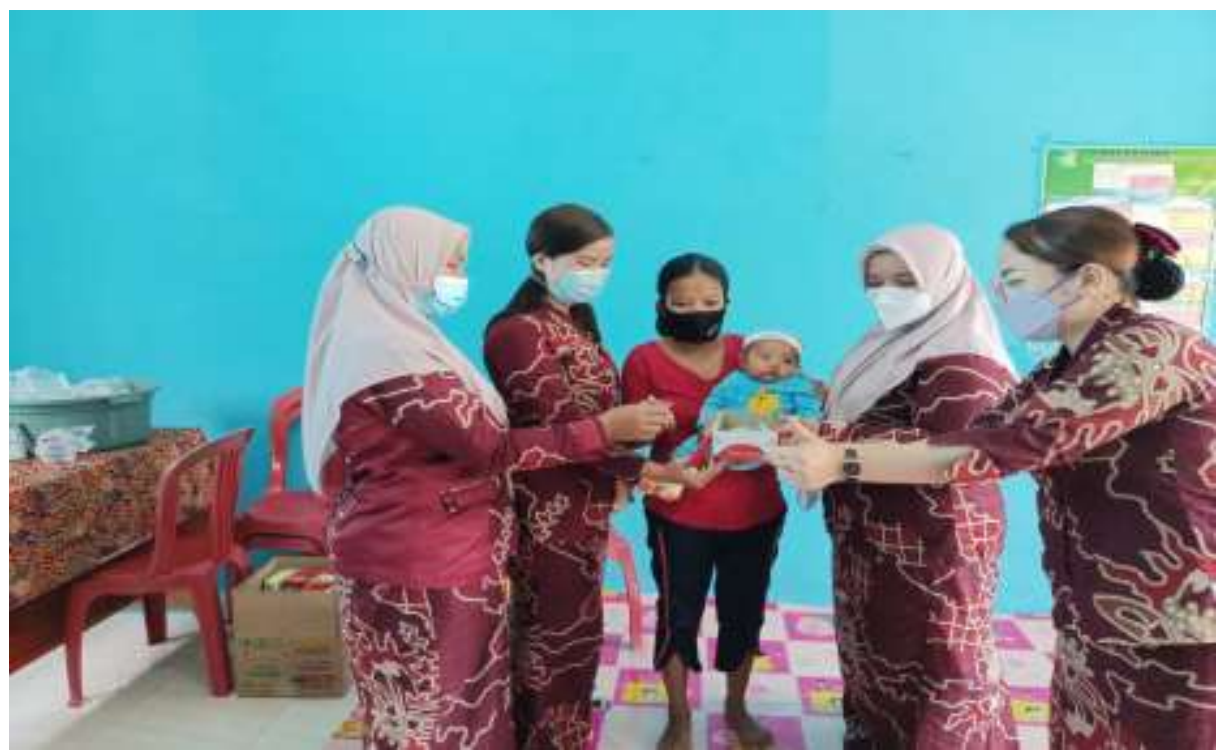

\section{KESIMPULAN}

Kesimpulan dari kegiatan gerakan masyarakat peduli gizi balita (gempita ) di desa warga indah jaya kecamatan banjar agung kabupaten tulang bawang adalah: adanya peningkatan pengetahuan ibu tentang gizi balita yang dapat meningkatkan berat badan bayi agar tidak terjadi kekurangan gizi pada anak.

\section{DAFTAR PUSTAKA}

Kusumawati, Evi, dkk.2020."Pengaruh Substitusi Yoghurt dan Tepung Kacang Hijau (Phaseolus radiates) Terhadap Penilaian Organoleptik, Kandungan 
Protein dan Kalsium Puding Silky Sebagai Makanan Tambahan Alternatif Untuk Anak Stunting”.JSTP: Vol 5. No 3 P

Purhadi, dkk."Pengaruh Pemberian Bubur Kacang Hijau Terhadap Perubahan Berat Badan Balita Dengan Status Gizi Kurang di Wilayah Kerja PuskesmasTawangharjo Kabupaten Grobongan”.Jurnal

Kemenkes RI.2020. "Profil Kesehatan Indonesia Tahun 2019”.Jakarta: Kementrian Kesehatan RI

Suksesty, Catur Erty, dkk.2020."Efektifitas Program Pemberian Makanan Tambahan Menggunakan Kombinasi Jus Kacang Hijau dan Telur Ayam Rebus Terhadap Perubahan Status Gizi Stunting di Kabupaten Pandeglang”.Jurnal IMJ:Vol 3

Iqmi, L. O., Yantina, Y., \& Astari, N. (2019). Penyuluhan Pemilihan Alat Kontrasepsi Keluarga Berencana (KB) di Dusun Margorejo II Desa Kurungan Nyawa Kabupaten Pesawaran Tahun 2018. Jurnal Perak Malahayati, 1(1).

Lathifah, N. S., Isnaini, N., Yantina, Y., Retnowati, R., \& Yustiana, L. (2021). Konseling Kesehatan Reproduksi Meningkatkan Pengetahuan Tentang Kesuburan Dan Kesadaran Kesehatan Prakonsepsi. JURNAL PERAK MALAHAYATI, 3(1), 51-60.

Susilawati, S., Lathifah, N. S., Astriana, A., \& Yantina, Y. (2020). Agar-Agar Daun Kelor Memperbanyak Asi Pada Ibu Nifas 0-3 Hari Di RSIA Santa Anna. JURNAL KREATIVITAS PENGABDIAN KEPADA MASYARAKAT (PKM), 3(2), 352-356. 